\title{
Improving School Leadership: Principals Orientation and Culture in Primary Schools of Ambo Town, Oromia Regional State, Ethiopia
}

\author{
Jeilu Oumer, Mekonnen Kejela
}

Addis Ababa University, Department of Educational Planning and Management, Addis Ababa

\begin{abstract}
The purpose of this study was to examine the relationship between the leadership orientation of principals and school culture as perceived by teachers. The design of the study was QUAN-qual of explanatory type where the quantitative type informed the qualitative phase of the study. A total of 55 teachers, from 3 complete primary (1-8) schools located in Ambo city administration in the zone of West Showa, Oromia regional state, Ethiopia, were randomly selected to involve in this study. The data for the study were collected using the School Culture Survey, which assessed six dimensions of school culture: collaborative leadership, teacher collaboration, and unity of purpose, professional development, collegial support, and learning partnership; and Leadership Orientation Questionnaire (LOQ) that categorized the leadership frames of principals into structural, human resource, political and symbolic frames. Frequencies, mean values, standard deviations, and Pearson product-moment correlation coefficients were used to present and analyze the results of the study. The findings indicate that structural and political frames of leadership were the dominant frames of the principals of the schools. Unity of purpose, professional development and collegial support were the prevailing cultures in the schools whereas the remaining: teacher collaboration, collaborative leadership, and learning partnership were the less popular school cultures as perceived by teachers. Besides, there were a positive, strong to moderate relationship between human resource frame, symbolic frame and structural frame of leadership and all the dimensions of school cultures except collegial support. It was concluded that the school principals had a narrow view of school leadership orientation and most of the school culture domains were not to the expected level in the school system. Therefore, it is suggested that building strong personal relationships with teachers and playing symbolic role of leadership contribute significantly to developing and maintaining collaborative school culture.
\end{abstract}

Keywords: School culture, structural frame, human resource frame, political frame, symbolic frames

\section{INTRODUCTION}

Schools improve when multiple elements are in place, including strong school leadership, a safe and stimulating learning climate, strong ethical and trusting relationships, increased teachers' professional capacity for instruction and leadership, student-centered instruction, and links to parents and the community. These features cannot occur without supportive, shared school culture.

School culture constitutes the context in which school leadership is exercised. Understanding, acting, and shaping school culture is desirable for any one working and living in the culture, but it is critical to school leaders (Schein, 2004).It has long been reported that paying attention to culture is the most important action that a leader should perform. There is also evidence (e.g. Fink and Resnick, 2001) that school principals are responsible for establishing a pervasive culture of teaching and learning in each school.

Brown (2004) and Raywid (2001) noted that to understand the contributing factors to the success of any community, business entity, or organization, it is important to study their culture; likewise, to understand the success of any school, it is critical to study its culture. By deepening their understanding of school culture, leaders will be better equipped to shape the values, beliefs, and attitudes necessary to promote a stable and nurturing learning environment (Stolp, 1994). The message here is that school culture is an important area of school leadership that contribute to school success. School culture is an area deserving researcher's attention to uncover the existing culture and its correlation with leadership. It is, therefore, important for school principals to know which leadership behaviors positively affect school culture and, ultimately, student learning. Tony (2007), in this 
regard, agreed that strong leadership behavior framed according to the demand of school culture is a foundation for school excellence.

\subsection{Framework of the Study}

The theory that views the multidimensional nature of leadership developed by Bolman\& Deal's $(1984 ; 1991 ; 1997)$ was preferred as a framework to see the school principal's leadership orientation. The authors consolidated major schools of organizational thought into four perspectives and came up with more comprehensive leadership framework to investigate and explain the complex phenomenon of leadership including culture leadership. The frames were: the structural frame, the human resource frame, the political frame, and the symbolic frame. School culture was also another variable examined in this study. Authors have tried to categorize school culture in a variety of dimensions considering variety of factors. Of the many dimensions of school culture, stuck and moving (Rosenholtz, 1989) plus wandering and promenading (Hopkins, Ainscow, \& West, 1994); fragmented individualism, balkanization, contrived collegiality, comfortable collaboration, and collaboration(Fullan\& Hargreaves, 1996); positive, toxicand those in between (Deal \& Peterson, 1999), constructive , passive defensive, aggressive defensive $($ cooke, 1989$)$ were some of the common ones. The dimensions above indicated the possible types of culture in the school; however, the dimensions that appear to be relevant for this study was the culture that assess and develop collaborative culture. Most researchers (Sarason, 1996; Fullan, 1992; Schlechty, 1997) noted that collaborative culture is the most effective one at school. Hence, the six Gruenert\& Valentine's (1998) collaborative cultural dimensions: collaborative leadership, teacher collaboration, professional development collegial support, unity of purpose, and learning partnership were the culture measures used in this study. These culture dimensions were believed to provide insight about the shared values, the patterns of activities, and interactions in the school. Thus, leadership orientations were examined in order that principals can work for a more complete understanding of how to mold a positive culture by appropriate use of leadership style for an ultimate gain in student performance. Leadership frames were treated as an independent variable and school culture dimensions were treated as a dependent variable.

\subsection{Statement of the Problem}

School culture is an area that goes unnoticed on one part and schools call for leadership behavior that promote a culture required to prepare students sufficiently for the coming modern world on the other. Despite the pervasive roles of leadership in school culture, little critical research attention has been devoted to understanding the links between the two concepts. The consequence of not understanding the embedded cultures, as Schein (1992) and Watson (2001) highlight, is, however, damaging to the leaders as well as student achievement. It must get the attention it deserves and play its functional role in education, with the main catalyst being the principals. It can be argued that very few leaders understand the importance of school culture and therefore do not take intentional action to shape it.

School improvement programs mainly focused by Education Sector Development Programs (ESDPs) and General Education Quality Improvement Programs (GEQIPs) on the human and material resource capacity, curriculum, leadership and management, pedagogy as factors of school improvement. Undoubtedly, these are the main factors of school improvement. However, it is indispensable to recognize that school improvement does not occur in a vacuum. It occurs in social systems that have beliefs, assumptions, expectations, norms, and values, that members identify themselves with and shared among themselves. Literature (Stolp, 1999) also evidenced that school culture has been one of the most neglected in school improvement.

Most of the local empirical studies reviewed also indicated the dysfunctional culture prevailing in some schools in Ethiopia. Hussein (2013) for instance, identified that a culture of blame, false reputation and abuse of data in primary schools. Similarly, Obang (2014) in his work found that there was low trust between principals and teachers of secondary schools. Un-conducive secondary school climate (Nebiyu, 2014) and less open and low intimacy of secondary teachers (Zebene, 2012) were also the findings indicative of the nature of school culture. Secondary school Teachers' weak professional development culture (Mekonnen, 2015), the less application of symbolic frame of leadership of female principal of primary school (Mekonnen, 2016) are also the findings on school culture. The culture of collaboration was rarely observed at schools. 
The purpose of this study was to examine the leadership orientation of school principals, the prevailing school culture, and the relationship between the two as perceived by primary school teachers. The basic questions that guided the study were:

1. How do primary school teachers perceive their principal's leadership orientation?

2. How do primary school teachers perceive their school culture?

3. What is the nature of the relationship between principal leadership orientation and school culture?

\subsection{Significance of the Study}

This study could be useful to higher education institutions that have educational leadership programs designed to prepare educators for principal ship positions. It could provide them with information that can be used to revise or supplement their programs in an effort to properly equip principals with the training that is needed for them to be effective in their schools.

It might also induce self-awareness and reflection in principals concerning their principal ship orientation and practices in view of school culture. It could initiate principals to assess and improve (if needed) the culture at their schools. It could encourage them to evaluate their own leadership orientation and make an effort to match their style with the needs of their schools.

\subsection{Delimitations of the Study}

The study was delimited to government primary schools in Ambo town. It was also delimited to the study of teachers' perception about principals' leadership orientation and school culture. Participants were only those teachers who served in the school for two years and above since it was believed that it requires teachers sometime to identify the leadership orientation of the principals and culture of the school. The study used contextualized Bolman and Deal's leadership orientations survey and Gruenert\& Valentine's (1998) school culture survey questionnaire. Only teachers were the participants of the study. As the sample size was small the findings were delimited only to those schools and principals involved in the study.

\subsection{Limitations of the Study}

The sample of this study was delimited to small scale (in terms of number of teachers and schools, and location). Therefore, the results of this study were limited with the perceptions and experiences of the sampled group. Given the size of the sample population, it was not possible to generalize the results of this survey to all primary schools in the region. Despite these limitations, it should also be noted that an educational study of this nature would hopefully contribute to the generation of valuable ideas and perspectives about educational leadership and school culture.

\subsection{Operational Definition of Terms}

School culture: adominant pattern of behaviors and beliefs held by teachers that actas a frame of reference for the way they interact and the way things are done at the school.

Frame: the angle from which school principals view school issues

Leadership frames: refers to Bolman and Deal's (1991) categorization of leaders' leadership orientation which school principals apply in their leading process

The structural frame: it is a school principal's leadership perspective that emphasizes task, goals, and policies.

The human resource frame: it is a school principal's leadership perspective that emphasizes meeting the needs of teachers, students and other school personnel.

The political frame: it is a school principal's leadership perspective that emphasizes on creating negotiation and coalition building.

The symbolic frame: it is a school principal's leadership perspective that emphasizes on inspiration of the soul of the teachers, students, and other school personnel with whom they work.

\section{REVIEW OF RELATED LITERATURE}

\subsection{School Culture}

There are many definitions of culture. Anthropologists, sociologists, and psychologists have contributed many definitions, all highlighting different aspects of the concept (Baker \&Campbell, 2013). For the purposes of this study, culture is a shared phenomenon (Davis, 1984\& Schein, 1990) that involves an intricate mix of beliefs, values, meanings and assumptions, which are manifested in 
an array of symbolic representations, such as ceremonies, artifacts and relationships (Schein,1992). School culture is not a different story. It is one of the most complex and important concept in education (Stoll, 1998) and it can be defined in a number of ways. Writers commonly define school culture as the normative adhesive that holds a specific school together (Hoy \& Hoy, 2006; Schein, 2004; Sergiovanni, 2000).According to Fullan (2007) school culture can be defined as the guiding beliefs and values evident in the way a school operates. School culture refers to the shared beliefs about how a school operates, the core values regarding a school's goals for its students, and the behavioral norms exhibited by teachers (Maslowski, 2006). Simply put, school culture can be used to encompass all the basic assumptions, behaviors and values, beliefs and practices that are shared by the members of a school community and shape interactions, decision-making, and daily routines within a school.

As culture is extremely powerful, it influences everything that goes on in schools: how staff dress, what they talk about, their willingness to change, the practice of instruction, and the emphasis given student and faculty learning (Deal \& Peterson, 1994; Firestone \& Wilson, 1985; Newmann\& Associates, 1996).Thus, in this study, school culture is defined as a dominant pattern of behaviors and beliefs held by school members that acts as a frame of reference for the way they interact and the way things are done at the school. Using this idea of a frame of reference allows for consideration of school members' responses to principal leadership as a function or expression of school culture.

\subsection{Dimensions of School Culture}

Authorities classified the culture into different dimension: For instance, stuck and moving (Rosenholtz, 1989) plus wandering and promenading (Hopkins, Ainscow \& West, 1994); fragmented individualism, balkanization, contrived collegiality, comfortable collaboration, and collaboration (Fullan\& Hargreaves, 1996); positive, toxic and those in between (Deal and Peterson, 1999), constructive, passive defensive, aggressive defensive ( cooke,1989) were some of the common ones. The categories raised above showed that some cultures are positive and some others are toxic to the functioning of an organization. However, the dimensions that appear to be relevant for this study should be the culture that assess and develop collaborative culture. The study intended to find how teachers feel about their students, how school principals relate and work with teachers, how teachers see professional development and work in partnership, whether teachers work in isolation or with colleagues and support each other, whether teachers have shared school vision, and their confidence in their collective abilities to achieve their ambitions.

The collaborative school culture dimensions that were believed to provide insight about this shared values, the patterns of activities, and the interactions in the school appeared to be the dimensions by Gruenert\& Valentine (1998). Each dimension, they believe, measures a distinctive feature of the school's shared values like collaborative culture (Gruenert\& Valentine, 1998). They were the instruments for the measure of school culture in this study. They identified six dimensions of school culture. These six factors were-collaborative leadership, teacher collaboration, professional development, collegial support, unity of purpose, and learning partnership. The succeeding sections will focus on these six dimensions of school culture.

\subsubsection{Collaborative Leadership}

Collaborative leadership is the extent to which teachers' ideas, suggestions, and contributions are accepted by school leaders, and how much school leaders trust, encourage, and consult teachers in decision-making (Gruenert, 2000; Gruenert\& Valentine,1998; Gumuseli \&Eryilmaz, 2011). It measures the degree to which school leaders establish and maintain norms of collaborative relationships with school staff. It is the leadership behavior in which they value teachers' ideas, seek input, engage staff in decision-making, and trust the professional judgment of the staff. They fostered collegiality and the opportunity for collaborative work among teachers centered on curriculum, instruction, and assessment.

In collaborative school culture principals and teachers share the burden of school improvement. Cunningham and Gresso (1993) noted that principals in collaborative schools are more actively involved in observing and evaluating teacher and in working with teachers on school issues. The existence of collaborative school culture together with shared leadership and professional networking holds the best prospects for the development of teacher' ability and shared beliefs and for students' overall achievement. 


\subsubsection{Teacher Collaboration}

This aspect of school culture deals with the extent to which teachers work together. It is the culture that promotes teachers engagement in constructive dialogue that furthers the educational vision of the school. Teachers' collaboration is about joint planning, observing and discussing teaching practices, and engagement in professional development practices, and school improvement programs (Fullan, 1993; Gentzler, 2005; Gruenert, 2000).

Teachers in collaborative culture are strongly committed to collaboration, fulfilling school-wide roles as decision-makers, coordinators of professional development, and leaders in the efforts to improve classroom instruction across the whole school. Leithwood et al. (2003) explain that collaborative culture promotes the exchange of thoughts and supports and joint problem solving by means of giving favorable conditions for exercise of teacher leadership, and appropriate stimulus for awaiting teacher leaders to gain experiences that will result in academic excellence.

\subsubsection{Professional Development}

Professional development measures the degree to which teachers' value continuous personal development and school-wide improvement. Professional development culture promotes teachers mutual support and advice for the purpose of continuous development in skill and knowledge that match with the need of the progressing world. It promotes performance environment and culture that both drives and inspires teachers to higher performance in the school. Professional development refers to a practice of enhancing one's professional skill and competence through workshops, professional growth seminars, trainings, resource persons, professional publications and other resources (Gruenert, 2000, Gruenert \& Valentine, 1998; Gumuseli \& Eryilmaz, 2011).

According to Peterson (2002), culture enhances professional learning when teachers believe that professional development is important, valued; meaning that professional development is nurtured when the school's history and stories include examples of meaningful professional learning and a group commitment to improvement. Staff learning is reinforced when sharing ideas, working collaboratively to learn, and using newly learned skills are recognized symbolically and orally in faculty meetings and other school ceremonies. Fulan and Hargreaves (1991) also agreed that collaborative schools have a culture in which teachers continuous professional development is facilitated through mutual support, joint work, and broad agreement on educational issues. Overall, professional development culture can be modeled in schools in which teachers are in frequent conversation with each other about their work, have easy and necessary access to each other's classrooms, assume that they should comment on each other's work, and have the time to develop common standards for student work ( Peterson, 1992).

\subsubsection{Collegial Support}

Collegiality refers to the quality of the relationships among staff members in a school and the extent to which teachers' engage in cooperative actions. Collegial support culture reflects the extent to which teachers work together effectively in all aspects of life. In line with this, Jarzabkowski (2000 used collegiality to describe teachers' involvement with their peers on any level, be it intellectual, moral, political, social and/or emotional. Equally to this definition, collegiality has a communal aspect; and it is a group property (Fielding, 1999). Collegial support culture view authentic teamwork as an essential characteristic of the successful organization as its members interact regularly to share their ideas and expertise and develop common understanding of organizational goals and the means to their attainment (Shah, 2012). Gentzler (2000) and Hoy and Hoy (2006) define collegial support specific to the work related support. Collegial support is the work-linked support that members provide to one another by sharing common concerns, information, experiences, and knowledge at the workplace. Similarly, Evans (2003) suggests that collegial support is an interpersonal relation, and includes features such as the degree and quality of teamwork, cooperative ways of working, consultation, and interdependence and support among colleagues. In such culture teachers trust each other, value each other's ideas, and assist each other and work together as they have a common purpose. In collegiality, as Little (1990) noted, strong interdependence, shared responsibility, and collective commitment are evident in collegial support culture.

Numerous benefits from teacher collegiality have been reported as evidence of the need for building a more effective collegial culture in schools. The most significant benefits of collegiality among teaching staff is an improvement in teacher professional growth and development (Jarzabkowski, 
2003). It is seen as an opportunity to involve many individuals in solving the complex educational problems of modern times (Shah, 2012). Teachers within each interdisciplinary team interact with each other actively and in a meaningful context. More experienced teachers are able to share their wisdom and experience, while less experienced teachers offer fresh insight. Ether widely or narrowly viewed, teacher collegiality is necessary in an era of continuous change and improvement.

\subsubsection{Unity of Purpose}

Unity of purpose is a culture of working toward a common mission of school. It refers to the degree to which teachers collectively focus on the common visions and objectives of the school (Gruenert\& Valentine, 1998). Sergiovanni ( 2000) further noted that unity of purpose provides the school with sense of direction and it is a key to success. Besides modeling, Deal and Peterson ( ) suggest that principals should work to develop shared visions-- rooted in history, values, beliefs. Fullan and Hargreaves (1991) suggested that collaboration is likely to work only when the principal and a significant number of teachers at a school become convinced that collaboration will actually lead to improved teaching and learning.

The vision of the school should mirror the hope, benefit, needs, values, and dreams of all stakeholders and teachers realize, support, and execute their duties in harmony with the visions of the school (Sergiovanni, 2000). A culture of a unity is one of the most important attributes of a team. A team that is united in vision, in culture and in purpose produces good fruit and continues to move forward. A team that lacks unity, however, is difficult to mobilize and to progress. Principals and teachers shared a common core of values and beliefs that guided programs and practices, including high expectations for all students, education of the whole child, all students will be successful, and a dedication to a coherent curriculum, student-centered instruction, and the effective use of formative and summative student data.

\subsubsection{Learning Partnership}

Learning partnership is a culture that promotes the engagement of students and staff effectively as partners in learning and teaching. It is understood as fundamentally as a relationship in which all involved - students, academics, professional services staff, senior managers, students' unions, and so on - are actively engaged in and stand to gain from the process of learning and working together. Learning partnership is a school culture reflected where teachers, parents, and students work together for the common good of the student. Members like parents and teachers share common expectations and communicate frequently about student performance. Parents trust teachers and students generally accept responsibility for their schooling (Gruenert, 2000, Gruenert \& Valentine, 1998; Gumuseli \& Eryilmaz, 2011).

Arthur-Kelly et al., 2006; Busher, 2003; believes that "it is our connections with our parents, children, spouses, siblings, friends, and teachers that provide us with meaning and genuine learning. According to Brown (2004), the root of culture is relationships. Good relationships create a conducive atmosphere for partnership. Partnership is essentially a process of joint working between students and staff. In this context partnership working is based on the values of: openness; trust and honesty; agreed shared goals and values; and regular communication between the partners. Partnership implies an equal relationship between two or more bodies working together towards a common purpose, respecting the different skills, knowledge, experience and capability that each party brings to the table.

\subsection{Leadership}

Numerous intensive and extensive theories of Leadership behavior and styles were evolved since the early 1600s (Yukl, 1989). Great Man Theory, Trait Theory, Behavioral Theories, Contingency Theories, and contemporary leadership theories were the most common ones dominantly known during specific times of the evolution. The theories were mainly categorized based on the premise that what makes the leaders more effective in leading. It is, however, important, as John van Maurik (1999) has remarked, to recognize that none of the theories was mutually exclusive or totally timebound. In the early 20 centuries the great man and Trait theories dominated the theories of leadership. The major assumption of the theories was that leaders are born not made.

From the late 1940s to late 1960s behavioral approach of leadership became dominant. The major premise of these theories was that effectiveness in leadership has to do with what leaders actually do. In the late 1960s to the early 1980s the Contingency Approach became popular proposing that 
leadership effectiveness is dependent upon the situation (Bryman, 1993). Contemporary views to leadership focus on vision and charisma, and transformation. In the midst of these arrays of leadership theories, Bolman and Deal (1991) suggested a comprehensive unique leadership model named 'leadership frame'. The model elaborate on four leadership frames that are potential lenses for school leaders. With the many leadership theories described here, there are aspects of each leadership theory that are found in Bolman and Deal's four-frame model. This model is considered as significant by many researchers in that it intends to assemble the partially highlighted aspects of leadership dimension into a whole one (Lee, 2008). This holistic perspective resulted to create the concept of multi-frame leadership, the main concern of which is to see thoroughly the leadership reality with more enlarged and enriched perspectives. The next section treated the theory in detail.

\subsubsection{The Leadership Frames}

The four leadership frames (Bolman and Deal, 1991) are potential lenses for school leaders. The term frame is defined as "windows of the world" as per the authors and that act as filters by letting things in easily while leaving out some others. Further, the authors suggest that leaders can understand the depth and complexity of organization life only when they view it from multiple frames. The elaborations of the four frames are presented below.

The leadership frames include: human resource, structural, symbolic and cultural, and political leadership. Each leadership style speaks to different frames or lenses, which leaders use to make decisions. The human resource lens frames the organization around human needs and the potential of man power. The human resource frame places an emphasis on a sense of family in the organization and provides a caring, nurturing, and supportive environment. The symbolic lens frames the organization around rituals and ceremonies that anchor the organization in a culture that creates consistency and routines. Honoring rituals and ceremonies reduces ambiguity in the organization and sometimes resolves conflicting view points. The political lens frames leadership decisions around the allocation of scarce resources. It presupposes that organizations are coalitions of individuals and interest groups. The political frame focuses on bargaining and negotiation. The cultural lens frames the organizational environment around how members think, feel, and act. The cultural frame brings value to stories that explain the past and anchor the present. Bolman and Deal (1991) describe these frames as multiple perspectives that principals employ as they lead in schools. In this study, the research focuses on the cultural frame and how the leader reads and uses culture in order to begin working within and lead the school. Bolman and Deal (2003) viewed leadership style as a frame; a framework within which organizational reality can be interpreted. The justification is that because the world of human experience is so complex and ambiguous, frames of reference shape how situations are defined and determine what actions are taken. The authors believe that attention needs to be given to how leaders set their mind about the work environment. In connection to the cognitive structure that guide the thinking and action of leaders, Bolman\& Deal (1992) suggest that the frames of reference that leaders operate from will determine the interpretation of their experiences and guide their actions. Durocher (1996) also commented that the cognitive structure of leaders is the core of multiple perspective frameworks.

They wrote of reframing the leadership orientations as a way to get beyond narrow and oversimplified views of leadership. For each, skills and processes are examined and rules of thumb are proposed for successful leadership practice. They purported that any one of the frames of leadership used by itself to address organizational existence would be inadequate. Each of the four frames offers a distinctive image of the leadership process but none is a perfect approach all the time in all situations (Bolman\& Deal, 2003).

Table1. A summary of what of a leader and leadership process according to Bolman and Deal

\begin{tabular}{|l|l|l|}
\hline Leadership Frames & A Leader is: & Leadership process is: \\
\hline Structural & analyst, architect & analysis, design \\
\hline Human Resource & catalyst, servant & support, empowerment \\
\hline Political & advocate, negotiator & advocacy, coalition building \\
\hline Symbolic & prophet, poet & inspiration, leadership experience \\
\hline
\end{tabular}

Adapted from Reframing Organizations: Artistry, Choice, and Leadership by Bolman and Deal (2003)

International Journal on Studies in English Language and Literature (IJSELL) 


\subsubsection{Multiple Leadership Frames}

Multi-frame leadership is basically a powerful tool that permits leaders to see and understand more about the organization as a whole. The multi perspective of this leadership style provides the ability to see new possibilities, challenges and also to create new opportunities that enable leaders to discover some alternatives to effectively solve the problems faced by the organization. This style of leadership consists of four frames of leadership: structural frame, human resources frame, political frame and symbolic frame. Each of the frames has its own image of reality; the skillful leader is one who can use multiple frames for this examination. One frame has the ability to express the story with that single perspective, while multiple frames aid the leader in seeing the story from multiple perspectives. You may be drawn to some and repelled by others. Some perspectives may seem clear and straightforward, while others seem puzzling. But learning to apply all four deepens your appreciation and understanding of organizations (Bolman and Deal (2008). Reframing allows the leader to identify the challenge clearly; to create different options; and to consider alternative strategies. Bolman and Deal (2003) wrote: Those who master the ability to reframe report a liberating sense of choice and power.

\subsubsection{Leadership Frames in Educational Organizations}

Leadership scholars emphasize the relevance of frame approach of leadership to educational organizations. In support of this idea, Goldman and Smith (1991) wrote that Bolman and Deal's four frames of leadership is most appropriate for defining school leaders, as all four frames appear in the school context. Schools are inherently people oriented places of business and as a result, schools are the embodiment of the human resource frame. In continuation, they pointed out that the diversity of school populations (students, parents, community, and staff) highlight the symbolic frame and its importance in the school setting.

The authors confirm that school leaders who can think wide and critically to view situations from more than one angle are more successful since schools are one of the complex organizations that exist as a result of a collective human endeavor (Bolman \& Deal, 2002). Bolman and Deal (2002) also state that school administrators are most successful when they are able to "look at things from more than one angle." Besides, as schools are complex organizations, so organizational experiences and information can be classified according to the cognitive orientations the leader is able to employ.

\subsection{Leadership and Culture}

Culture and leadership are two sides of the same coin and neither can really be understood without considering the other. But, one could ask whether the culture's power to change the principal is greater than principal's power to change a school's culture. There were some authors who have argued in the side of school culture power to influence the principal. In their view, a principal's efforts to significantly change school culture can only lead to frustration and defeat. One line of argument was that the interplay between the two is complex and difficult to decide the direction of the effects of one on the other (Piggott, 2016; Mozaffari, 2008 \&Bass, 1991). They noted that school leadership and school culture can also be defined as nested processes. Others argue (including me) that the power of leadership should not be ignored. For instance, Maehr and Parker (1993) reminded us that "leaders are not simply the enslaved of culture. They can and do affect it." The principal is certainly subject to the norms and other socializing forces of the school. As Renchler (1992) noted, the dynamics and logistics of most schools are such that the principal cannot possibly oversee the motivational needs of each and every student. But groups of people can be affected by the culture in which they participate, and this domain is under the control and stewardship of the principal. Emphasizing the greater role of leadership in school culture change and development, Schein (1985) wrote that "Leadership is intertwined with culture formation." Developing an organizational culture and shaping the creative process of its evolution is the "unique and essential function" of leadership. Schein advised that the principal alone cannot bring about change in the persona of the school; cultural transformation is a collaborative activity. The principal must engage others both inside and outside the school if he or she is to cause any significant changes in the school's culture (Schein, 1985; Snowden and Gorton, 1998; \& Bass, 1991).

Firestone and Wilson (1995) were also those in support of the second line of argument. They said the actions of a building principal are central to the development of a school culture that is conducive to high levels of academic achievement and learning. Trice (1993) also noted that leadership and culture 
are intimately linked, and a school's culture can be developed, influenced, and managed. Douglas Reeves (2007) concluded the argument by noting, "Meaningful school improvement begins with cultural change and cultural change begins with the school leader".

Most empirical studies also favored the second line of argument. Valentine (2006) for instance, focusing the interplay between leadership and school culture, found that the decisive functions of leadership may well be the creation, the management and, if and when it becomes necessary, the destruction of culture. Gruenert (2005) also studied the relationship of leadership, school culture and student achievement. His conclusion was a culture that is collaborative depends on the leadership of the principal. Furthermore, some other empirical studies (e.g. Leclear, 2005; Dupont, 2009) revealed the existence of cause effect relationship between leadership (instructional, transformational) factors and school culture; and with the independent factor to be leadership. Still other researchers (e.g Cemaloglu, 2011; Kythreotis et al., 2010; Leithwood \& Sun, 2012; Hallinger, 2011\&Sahin, 2011) have demonstrated that the principal leader plays a significant role in the development of a positive school culture. Leclear (2005) specifically noted that principals leadership style enhance, shape and nurture school culture. The evidences raised above indicated that school principals are able and responsible to create, nurture and develop positive school culture if they work collaboratively with teachers, students and other stakeholders. They also uncover that school culture is built on the history and deep values of the school society; however, replacing and renovating the school culture is contributed to through the basic function of the leader.

Principals need to be supporters and providers for teachers, creating opportunities for growth and change. Building a positive school culture has been considered to be inextricably intertwined with the people who inhabit the school. Positive relationships between the principal and school staff have been deemed vital (Fullan, 2002). The human resources frame described by Bolman and Deal (2008) plays a pivotal role in effective leadership practices for shaping a positive school culture. Effective leadership, as argued by Hopkins, Ainscow and West (1994), requires a change from a style which emphasizes direction and control, to one which emphasizes delegation and empowerment, in which the leadership functions are widely shared. Such a style of leadership is concerned with changing values and beliefs, with developing and communicating a shared vision for the future of the school, and with inspiring, motivating and empowering staff. The principal then needs to bring everyone on board to change the culture by sharing leadership. Deal and Peterson (1999) believe that deep and shared leadership creates the strongest and tightest cultures.

Many different leadership models are effective in shaping a positive culture that continuously improves a school. The theories that brought the focus onto culture as a byproduct of leadership centered on Bolman and Deal's model $(1984,1991)$ of leadership and this was a theoretical frame of this study. Building collegiality and collaboration on the shared goals and values, encouraging staff development that is student oriented, modeling behaviors that encourage student achievement, and celebrating and rewarding teachers by sharing stories of success and accomplishments are also positive steps toward the building of culture (Leithwood \& Jantzi, 1990; Schein, 1992).

Overall, culture and leadership are two sides of the same coin and neither can really be understood without considering the other. There were wider agreements that leadership and school culture are correlated. Attempting to understand one without having an understanding of the other will not obtain the desired results. It was well evidenced; however, that a principal, more than any other individual, is responsible for a school's culture. The most effective change in school culture happens when principals, among others, model the values and beliefs important to the institution. A principal, who acts with care and concern for others, share leadership, support and develop staff capacity, and model collegiality and collaboration, inspiring staff with shared vision and purpose is more likely to develop a school culture with similar values.

\section{RESEARCH DESIGN AND METHODOLOGY}

\subsection{Research Design}

The purpose of this study was to explore the relationship between leadership and school culture. Mixed methods research design of QUAN-qual type was employed. The quantitative study result informed the qualitative data to be collected and it was thus an explanatory mixed method type. The decision was to explain the survey results already obtained more. The other reason was to get flexibility (Bryman, 2004) of combining objective theories (Creswell, 2009) that are considered to be 
accurate, credible, and scientifically rigor (Bryman, 2004) with insights, meanings, reflections individual principals and teachers ascribe. I followed a mixed methods analysis (Creswell \& Clark, 2011). These design allowed me for better understanding of the initial quantitative result, adding more depth and richness to the study and then reinforced my decision.

\subsection{Sources of Data}

The study was carried out in 3 primary schools found in Ambo city administration. Fifty- five teachers participated in the quantitative phase and 3 teachers, 1 vice principal and 1 principal totally 5 respondents participated in the qualitative phase of the study.

\subsection{Data Collection Instruments}

Leadership Orientations Questionnaire (Bolman\& Deal, 1990) and school culture survey (Gruenert $\&$ Valentine, 1998) were data collection instruments for the first phase of data collection. Due to the linguistic, interpretative, and culture related differences to use directly the survey instruments, the researcher had made a pre-study of the instruments in translating and adapting the tools by experts and pilot testing. The final checkup resulted inacceptable Cronbach's alpha values for both instruments.

\subsection{Data Collection Procedures}

First, the quantitative data were collected and analyzed. Then the qualitative data were collected on major findings of the survey data through semi-structured interview and observation for further explanation. Then, semi-structured interview guide was prepared based on the findings. During the actual interview, many relevant probing questions that were mainly the consequent of the answers to the prior questions were raised. School B was purposely selected for qualitative data source based on its higher weighted mean values on structural and political frame. Teachers' interaction in school compound was observed by the help of observation checklist.

\subsection{Data Analysis}

Both descriptive and inferential statistics like frequencies mean scores, standard deviations, Pearson correlation coefficients were used for analysis. Software SPSS version 20 was used for ease of computation of the data. A multiple regression identifies the best combination of predictors (independent variables) of the dependent variable. The mean scores reflective of the level of use of the frames were categorized, as already described above, into three levels; such as low (below 2.5), moderate (2.5-3.5), and high (above 3.5). Leadership frame use and the existence of school culture were operationally set at 3.5 and above. Further explanations were made on the major findings with the help of qualitative data.

\section{RESULTS AND DisCUSSIONS}

\subsection{Demographic Data}

Out of the 55 teachers who participated in the survey phase and completed the demographic section, $19(34.5 \%)$ were males and $36(65.5 \%)$ were females. Nearly more than half of the respondents $(54.6$ $\%$ ) fell below an age of 36 , and nearly a quarter of them were above the age of 45 . Most respondents (about 64\%) have an experience of more than 5 and less than 20. But no one respondent was in the age range of less than 5 and above 40. Most of the respondents' current school experience is greater than 2 and less than 10 (83.6\% out of which $58.2 \%$ have experiences that lie in the range of 6-10).

The overall explanation related to age and work experience was that most of the teacher respondents were highly experienced both in aggregate and in current school and it can be assumed that they have experienced what has been going on in the school and could give accurate data. With regards to educational level of participants, except two teachers (3.6\%), the remaining 53 (96.4) were either diploma or degree holders. The highest level of education by percentage of all respondents was diploma $(54.5 \%)$. Nearly $70 \%$ of the respondents had a specialization in either language or social sciences streams.

\subsection{Analysis of the link between Leadership and School Culture}

\subsubsection{Principals Leadership Orientation}

The Leadership Orientation Questionnaire (LOQ) developed by Deal and Bolman (1994) was used to assess teachers ratings of the leadership orientations of principals as described by items subdivided among the four frames of leadership( structural, Human resource, Political, and symbolic).The findings were presented in Table 2. 
Improving School Leadership: Principals Orientation and Culture in Primary Schools of Ambo Town, Oromia Regional State, Ethiopia

Table2. Leadership Orientation of School Principals

\begin{tabular}{|l|c|c|c|c|c|}
\hline & $\mathrm{N}$ & Minimum & Maximum & Mean & SD \\
\hline Structural Frame & 55 & 2.50 & 5.00 & 3.81 & 0.59 \\
\hline Human Resource Frame & 55 & 1.00 & 5.00 & 3.20 & 1.26 \\
\hline Political Frame & 55 & 2.25 & 5.00 & 3.74 & 0.61 \\
\hline Symbolic frame & 55 & 1.13 & 5.00 & 3.32 & 1.10 \\
\hline
\end{tabular}

The teachers rated their principals higher in the use of both the structural frame $(\mathrm{M}=3.81$ and $\mathrm{SD}=.57)$ and political frame $(\mathrm{M}=3.73$ and $\mathrm{SD}=.6)$ whereas average in the use of symbolic leadership orientation $(\mathrm{M}=3.32$ and $\mathrm{SD}=1.09)$ and human resource orientation $(\mathrm{M}=3.2$, and $\mathrm{SD}=1.26)$. These findings suggested that the school principals have emphasized more of task accomplishments and the creation of strong power bases. Leadership frames literatures, however, noted that leaders should hold the capability to encompass cognitive complexity in the decision-making process to handle the contending demands between caring out responsibility (structural), handling institutional conflict (political), creating friendship and harmony (human resource), and exhibiting loyalty and enthusiasm (symbolic). Emphasizing on the wider view of leadership, Sheilds (2005) and Day, Harris, Hadfield, Tolley and Beresford (2000) explained that the duties of a head teacher are not only limited to carrying out functional duties like organizing, coordinating and evaluating but they also need to be a role model and source of inspiration to all the teachers. Similarly, Bolman and Deal ( 2003) found leaders, in education and business, who use three or more frames are perceived as being more effective than those who consistently use fewer than three frames. This finding was partially consistent with the findings of Mekonnen (2015) which found out that one of the two female principals studied were more of structural and political by orientation and the other was more of human and symbolic; and partially inconsistent with Bolman and Deal's (2002) and Toddy's (2010) that revealed as most educators rely primarily on the human resource frame.

Results from qualitative study allowed me to better understand the initial survey result by adding more depth and richness to the study. Most of the data were supplementing and complementing one another. Specifically, the result of observation of school B told me the less symbolic and the less considerateness of the principal. Attendance was seemed an end of the game for the principal. No one else, but it was him who attend the attendance of teachers standing erect near where the attendance document was found. Everyone teacher was coming targeting the attendance and getting back immediately after signing without any teacher greeting the director at least by gesture. I found no one teacher on the flag ceremony except the principal advising students in queue about some dos and don'ts.

The relationship between teachers and the principal seem not smooth. One does not observe sense of cooperation and community. The principal seems to have less trust and respect for teachers. The power distance seems wider. The relation of the principal was more to those up the educational hierarchy, or other sectors than the subordinates. One senior teacher interviewee (TM1) explained his concern about the consideration, the value and respect they luck from the principal. "His major approach is to instruct what to do and how to do. He shouted at you when he tells you something which is not the norm. You find him rarely with teachers or sometimes in the school compound. His common words were punishment, rules and regulations; and these were orders from the superiors and they are the common mottos he uses". The other senior female teacher (TF1) frankly told that "you never hear any motivating or inspiring talk from his mouth. You always hear a word of warning for not meeting expectations". She did not keep back what also existed among teachers and the major cause for that. She expressed that, "there is a bad culture in our school. I have never seen such a school in which teachers and a principal are at odds to each other. Truly speaking, but, it is the principal primarily responsible for our lack of unity." The other teacher's (TF2) view was also congruent with others. She focused on his usual words. She said, "You do because you are paid; if not you are not paid that is it"

The other male interviewee (TM2) in particular emphasized his principal's frequent application of structural frame when he says, "he told vice principals, teachers, students the routines of the day formally, in case he disappeared from the campus." laugh... he continually phone to the vice principals to check what is going on in the school doubting of the decision of the principals. The viceprincipal (VP) of the case school confirmed that they were not empowered to make decisions. Indeed, 
in practice, the vice-principals generally preferred asking their principal's opinions or agreement before making decisions. The principal $(\mathrm{P})$ also stated his approach that although imposition might appear unacceptable, it was necessary to establish compliance on the part of the teachers and staff to policies and directions of higher authorities. They believed that once structure and policies were established, schools would run smoothly and management would have little challenge.

Literature suggest leaders to use more than one frame to act effectively and make clear judgments. In this study, the principals' emphasized two out of the four frames - the structural frame, and the political frame. Such limited orientation could emanate from capacity problem- skill and knowledge gap or the existing culture both national as well as organizational, and other mediating factors like personal characteristics.

\subsubsection{Results of School Culture Dimensions}

The School Culture Survey developed by Gruenert and Valentine (1998) was used to assess teachers' ratings of their school's culture as described by six factors: collaborative leadership, teacher collaboration, unity of purpose, professional development, collegial support, and learning partnership. The results were presented in Table 3 below.

Table3. Mean Scores of the School Culture Dimensions as Perceived by Teachers

\begin{tabular}{|l|l|c|c|c|c|c|c|}
\hline \multicolumn{2}{|l|}{ Sample school } & $\begin{array}{c}\text { Collaborative } \\
\text { leadership }\end{array}$ & $\begin{array}{c}\text { Teachers } \\
\text { collaboration }\end{array}$ & $\begin{array}{c}\text { Collegi } \\
\text { al } \\
\text { support }\end{array}$ & $\begin{array}{c}\text { Unity } \\
\text { of } \\
\text { purpose }\end{array}$ & $\begin{array}{c}\text { learning } \\
\text { partnershi } \\
\text { p }\end{array}$ & $\begin{array}{c}\text { Professional } \\
\text { development }\end{array}$ \\
\hline \multirow{2}{*}{$\begin{array}{l}\text { School } \\
\text { C }\end{array}$} & Mean & 3.54 & 3.4 & 3.83 & 3.96 & 3.36 & 3.73 \\
\cline { 2 - 8 } School & SD & .65 & .58 & .581 & .68 & .72 & 0.71 \\
\cline { 2 - 8 } B & SD & 2.74 & 2.66 & 3.43 & 3.49 & 2.78 & 3.36 \\
\hline \multirow{2}{*}{$\begin{array}{l}\text { School } \\
\text { A }\end{array}$} & Mean & .756 & .75 & .76 & .53 & .77 & 0.70 \\
\cline { 2 - 8 } & SD & .53 & 4.27 & 4.46 & 4.47 & 4.04 & 4.36 \\
\hline \multirow{2}{*}{ Total } & Mean & 3.49 & .56 & .58 & .56 & .58 & 0.46 \\
\cline { 2 - 8 } & SD & .89 & .91 & .73 & .70 & .86 & 0.73 \\
\hline
\end{tabular}

School culture domains in the highest mean value was professional development culture $\mathrm{M}=3.8$ $(\mathrm{SD}=.75)$. The teachers somewhat agreed that there was a culture of engaging in continuous professional development in their schools. The culture of collegial support had a mean value of $\mathrm{M}=3.9$ $(\mathrm{SD}=.76)$. This result also suggested that the teachers somewhat worked together by respecting the ideas and beliefs of their colleagues. Besides, the respondents showed their agreement with the existence of unity of purpose culture $(\mathrm{M}=3.96(\mathrm{SD}=.70)$ that suggested the teachers in their schools shared a school mission and worked for its realization. In all the mean values the standard deviations were smaller indicating that there was not much variation among respondents perception on the three school culture factors. The school culture dimensions of learning partnership with $\mathrm{M}=3.38(\mathrm{SD}=.85)$, teacher collaboration with the mean value $\mathrm{M}=3.43$ ( $\mathrm{SD}=.91$ ), and collaborative leadership with the mean value $\mathrm{M}=3.48(\mathrm{SD}=.89)$ were rated average by teachers.

These findings could reflect that the teachers were doubtful of whether teachers, parents, and students in their schools worked together for the common good of the student or engaged in constructive dialogue that furthers the vision of the school or school principals included teachers in the decision-making process in that order. This study was nearly congruent with a study in Ethiopia by Korso (2013) who found the highest result for unity of purpose $(M=3.89, S D=0.99)$ and the lowest for learning partnership ( $\mathrm{M}=3.37)$. But it was different to some extent when compared against a study in US by Herndon (2007). One of the differences was that most of the cultural dimensions were perceived as higher except teacher collaboration $(\mathrm{M}=3.59, \mathrm{SD}=.32)$.In the two studies in Ethiopia, learning partnership was perceived as lower (Korso: $M=3.37, S D=1.26$ ) and Mekonnen: $\mathrm{M}=3.38$ and $\mathrm{SD}=.85)$ whereas higher in US $(\mathrm{M}=3.86, S D=0.31)$. These differences of result might be attributed to the differences in culture of leadership of countries. In the leadership orientation study it was found that the leaders were found more of structural and political by orientation. The school culture study also showed gaps in partnership and collaboration culture.

\subsubsection{Correlation Results Between Leadership Orientation and School Culture}

A Pearson correlation coefficient was calculated to determine the relationship between leadership orientations and school culture as depicted in the following table. 
Improving School Leadership: Principals Orientation and Culture in Primary Schools of Ambo Town, Oromia Regional State, Ethiopia

Table4. The Correlation Coefficient among Leadership Orientations and School Culture Dimensions

\begin{tabular}{|l|l|c|c|c|c|c|c|}
\hline \multicolumn{2}{|l|}{} & $\begin{array}{c}\text { Professional } \\
\text { developmen } \\
\mathrm{t}\end{array}$ & $\begin{array}{c}\text { Teachers } \\
\text { collaboratio } \\
\mathrm{n}\end{array}$ & $\begin{array}{c}\text { Collegi } \\
\text { al } \\
\text { support }\end{array}$ & $\begin{array}{c}\text { Unity of } \\
\text { purpose }\end{array}$ & $\begin{array}{c}\text { learning } \\
\text { partnershi } \\
\mathrm{p}\end{array}$ & $\begin{array}{c}\text { Collaborativ } \\
\text { e leadership }\end{array}$ \\
\hline \multirow{2}{*}{$\begin{array}{l}\text { Structura } \\
\text { 1 Frame }\end{array}$} & $\begin{array}{l}\text { Pearson } \\
\text { Corr. }\end{array}$ & $.554^{* *}$ & $.553^{* *}$ & $.430^{* *}$ & $.442^{* *}$ & $.400^{* *}$ & $.625^{* *}$ \\
\cline { 2 - 7 } & Sig. (2-tailed) & .000 & .000 & .001 & .001 & .002 & .000 \\
\hline $\begin{array}{l}\text { Hum. R. } \\
\text { Frame }\end{array}$ & $\begin{array}{l}\text { Pearson } \\
\text { Corr. }\end{array}$ & $.515^{* *}$ & $.671^{* *}$ & $.373^{* *}$ & $.486^{* *}$ & $.456^{* * *}$ & $.755^{* *}$ \\
\cline { 2 - 8 } & Sig. (2-tailed) & .000 & .000 & .005 & .000 & .000 & .000 \\
\hline $\begin{array}{l}\text { Political } \\
\text { frame }\end{array}$ & $\begin{array}{l}\text { Pearson } \\
\text { Corr. }\end{array}$ & $.464^{* *}$ & $.426^{* *}$ & $.338^{*}$ & $.347^{* *}$ & $.305^{*}$ & $.443^{* *}$ \\
\cline { 2 - 8 } & Sig. (2-tailed) & .000 & .001 & .012 & .010 & .024 & .001 \\
\hline \multirow{2}{*}{$\begin{array}{l}\text { Symboli } \\
\text { c frame }\end{array}$} & $\begin{array}{l}\text { Pearson } \\
\text { Corr. }\end{array}$ & $.514^{* * *}$ & $.624^{* *}$ & $.337^{*}$ & $.473^{* *}$ & $.354^{* *}$ & $.745^{* *}$ \\
\cline { 2 - 8 } & Sig. (2-tailed) & .000 & .000 & .012 & .000 & .008 & .000 \\
\hline
\end{tabular}

**. Correlation is significant at the 0.01 level (2-tailed)

*. Correlation is significant at the 0.05 level (2-tailed)

As per the data obtained, a strong positive correlations(r $(53)>.7, p<.05)$ were found between human resource frame and the two school culture factors of collegial support and teachers' collaboration; and between symbolic frames of leadership and school culture factors of collaborative leadership and unity of purpose. Others have all moderate positive relationship ( $\mathrm{r}(53)>0.3 \&<0.7, \mathrm{p}$ $<.05)$. Except the correlation between political frame and collegial support, political frame and learning partnership; and symbolic frame and collegial support that were significant at .05 degree of freedom, all other correlations were significant at .01 levels. This meant that 23 of the 24 correlations that were calculated in this study were statistically significant at the .01 and the remaining 3 were significant at .05 levels. This suggested that the chance factors were very minimal and the confidence level was $99 \%$. Hence, there were a statistically significant positive relationship between most of the leadership frames of principals and the factors of school culture. An increase in the use of principals' leadership frame could likely increase the collaborative culture of the school.

\subsubsection{Regression Results Between Leadership Frames and School Culture}

Based on the significant relationships observed, multivariate linear regression analysis was run to evaluate the prediction power of leadership practices on school culture. Thus, the predictor (independent) variables were the four leadership frames - structural, human resource, political, and symbolic. The criterion (dependent) variables were the six domains of school culture - teacher collaboration, unity of purpose, professional development, learning partnership, collegial support, and collaborative leadership. The significance level for the statistical tests was set at $\alpha=.05$.ANOVA and model summary were observed in the analysis. Table 5 to Table 10 presented the results the regression analysis.

Table5. Regression Coefficients of Teachers' Collaboration on Leadership Frames

\begin{tabular}{|l|l|c|c|c|c|c|}
\hline \multicolumn{2}{|l|}{ Model } & \multicolumn{2}{|c|}{$\begin{array}{c}\text { Un-standardized } \\
\text { Coefficients }\end{array}$} & $\begin{array}{c}\text { Standardized } \\
\text { Coefficients }\end{array}$ & \multirow{2}{*}{ Sig. } \\
\cline { 3 - 8 } \multicolumn{2}{c|}{1} & B & Std. Error & Beta & & \\
\hline \multirow{7}{*}{1} & (Constant) & 1.45 & .372 & & 3.89 & .000 \\
\cline { 2 - 8 } & Structural Frame & .29 & .265 & .308 & 1.10 & .277 \\
\cline { 2 - 8 } & Human resource Frame & .49 & .43 & .59 & 3.76 & .006 \\
\cline { 2 - 8 } & Political Frame & .49 & .344 & .568 & 1.42 & .162 \\
\cline { 2 - 8 } & Symbolic Frame & -.43 & .302 & -.516 & -1.43 & .159 \\
\hline
\end{tabular}

Dependent Variable: Teachers collaboration

A multiple linear regression was calculated predicting teachers' collaboration based on leadership frames of principals and a significant regression equation was found at $\mathrm{F}(4,50)=12.71, \mathrm{p}<.05, \mathrm{R}^{2}=$ .50 .With regards to the specific attribute, human resource was found the only predictor of teachers collaboration $(\mathrm{B}=.59, \mathrm{t}(53)=3.76, \mathrm{P}<.05)$. The predictor variable structural frame, political frames 
and symbolic frame were found insignificant predictors of the outcome variable teacher collaboration. Thus, human resource leadership frame could explain $59 \%$ of the change teachers' collaboration.

Table6. Regression Coefficient of Professional Development on Leadership Frames

\begin{tabular}{|c|c|c|c|c|c|c|}
\hline \multirow{2}{*}{\multicolumn{2}{|c|}{ Model }} & \multicolumn{2}{|c|}{$\begin{array}{c}\text { Unstandardized } \\
\text { Coefficients }\end{array}$} & \multirow{2}{*}{$\begin{array}{c}\begin{array}{c}\text { Standardized } \\
\text { Coefficients }\end{array} \\
\text { Beta }\end{array}$} & \multirow[t]{2}{*}{$\mathrm{t}$} & \multirow[t]{2}{*}{ Sig. } \\
\hline & & B & Std. Error & & & \\
\hline \multirow[t]{5}{*}{1} & (Constant) & 2.12 & .332 & & 6.38 & .000 \\
\hline & Structural Frame & .412 & .236 & .531 & 2.74 & .008 \\
\hline & Human Resource Frame & -.145 & .194 & -.243 & -.75 & .460 \\
\hline & Political Frame & .620 & .307 & .877 & 2.03 & .049 \\
\hline & Symbolic Frame & -.40 & .270 & -.578 & -1.46 & .147 \\
\hline
\end{tabular}

Dependent Variable: Professional development

A multiple linear regression was calculated predicting professional development based on leadership frames of principals. A significant regression equation was found $\left(F(4,50)=8.9, p<.05, R^{2}=.65\right.$. With regards to the specific frame, structural frame was found he only predictor of professional development $(\mathrm{B}=.53, \mathrm{t}(53)=2.74, \mathrm{P}<.05)$. The predictor variable human resource, political frames and symbolic frame were found insignificant predictors of the outcome variable professional development. The result indicated that about53\%of the variation in professional development could be attributed to the structural orientation of the principal.

Table7. Regression Coefficient of Collegial Support on Leadership Frames

\begin{tabular}{|c|c|c|c|c|c|c|}
\hline \multirow{2}{*}{\multicolumn{2}{|c|}{ Model }} & \multicolumn{2}{|c|}{$\begin{array}{l}\text { Unstandardized } \\
\text { Coefficients }\end{array}$} & \multirow{2}{*}{$\begin{array}{c}\text { Standardized } \\
\text { Coefficients } \\
\text { Beta } \\
\end{array}$} & \multirow[t]{2}{*}{$\mathrm{t}$} & \multirow[t]{2}{*}{ Sig. } \\
\hline & & B & Std. Error & & & \\
\hline \multirow[t]{5}{*}{1} & (Constant) & 2.95 & .403 & & 7.33 & .000 \\
\hline & Structural Frame & .148 & .287 & .187 & .517 & .608 \\
\hline & Human Frame & .112 & .235 & .185 & .477 & .635 \\
\hline & Political Frame & .382 & .372 & .530 & 1.03 & .309 \\
\hline & Symbolic Frame & -.358 & .327 & -.510 & -1.10 & .279 \\
\hline
\end{tabular}

Dependent Variable: Collegial support

The regression of leadership frames with collegial support culture dimension yielded some interesting and valuable insights. The influence of all the frames non-significantly affected the outcome of collegial support $\left.\mathrm{F}(4,50)=2.65, \mathrm{P}=.054, \mathrm{R}^{2}=.17 \mathrm{~ns}\right)$. Only $17 \%$ of the change in the collegial support culture of the schools was attributed to the leadership frame factors.

Table8. Standardized Regression Coefficient of Learning Partnership on Leadership Frames

\begin{tabular}{|c|c|c|c|c|c|c|}
\hline \multirow{2}{*}{\multicolumn{2}{|c|}{ Model }} & \multicolumn{2}{|c|}{$\begin{array}{c}\text { Unstandardized } \\
\text { Coefficients }\end{array}$} & \multirow{2}{*}{$\begin{array}{c}\begin{array}{c}\text { Standardized } \\
\text { Coefficients }\end{array} \\
\text { Beta }\end{array}$} & \multirow[t]{2}{*}{$\mathrm{t}$} & \multirow[t]{2}{*}{ Sig. } \\
\hline & & $\mathrm{B}$ & Std. Error & & & \\
\hline \multirow[t]{5}{*}{1} & (Constant) & 2.626 & .429 & & 6.116 & .000 \\
\hline & Structural & -.048 & .306 & -.054 & -.158 & .875 \\
\hline & Human resource Frame & .553 & .251 & .683 & 2.20 & .002 \\
\hline & Political frame & .325 & .397 & .402 & .819 & .417 \\
\hline & Symbolic frame & -.578 & .349 & -.735 & -1.659 & .103 \\
\hline
\end{tabular}

Dependent Variable: Learning partnership

A significant regression equation was found $\left(F(4,50)=4.22, p<.005, R^{2}=.25\right.$. With regards to the specific frame, human resource frame was the only significant predictor of learning partnership $(\mathrm{B}=.68, \mathrm{t}(53)=2.20, \mathrm{P}<.05)$. The result indicated that about $68 \%$ of the variation in learning partnership could be attributed to the human resource orientation of the principal.

Table9. Regression Coefficient of Collaborative Leadership on Leadership Frames

\begin{tabular}{|l|l|c|c|c|c|c|}
\hline \multicolumn{2}{|c|}{ Model } & \multicolumn{2}{|c|}{$\begin{array}{c}\text { Unstandardized } \\
\text { Coefficients }\end{array}$} & $\begin{array}{c}\text { Standardized } \\
\text { Coefficients }\end{array}$ & \multirow{2}{*}{ Sig. } \\
\cline { 3 - 6 } \multicolumn{2}{|c|}{} & B & Std. Error & Beta & & \\
\hline 1 & (Constant) & 1.309 & .325 & & 4.025 & .000 \\
\hline
\end{tabular}


Improving School Leadership: Principals Orientation and Culture in Primary Schools of Ambo Town, Oromia Regional State, Ethiopia

\begin{tabular}{|l|l|c|c|c|c|c|}
\hline \hline \multirow{7}{*}{} & Structural frame & .126 & .264 & .155 & .477 & .635 \\
\cline { 2 - 7 } & Human resource frame & .217 & .190 & .308 & 1.143 & .259 \\
\cline { 2 - 8 } & Political frame & .003 & .300 & .003 & .009 & .993 \\
\cline { 2 - 8 } & Symbolic frame & .305 & .231 & .392 & 2.320 & .03 \\
\hline
\end{tabular}

Dependent Variable: Collaborative leadership

A significant regression equation was found $\left(\mathrm{F}(4,50)=18.79, \mathrm{p}<.05, \mathrm{R}^{2}=.60\right.$. With regards to the specific frame, symbolic frame was the only significant predictor of learning partnership $(B=.39, t$ $(53)=2.32, \mathrm{P}<.05)$. The result indicated that about $39 \%$ of the variation in learning partnership could be attributed to the symbolic orientation of the principal; meaning that, each one-point increase in symbolic actions above the sample mean predicts increase of 0.39 points in collaborative leadership.

Table10. Multiple Regression Coefficients of Leadership Frames on Unity of Purpose

\begin{tabular}{|c|c|c|c|c|c|c|}
\hline \multicolumn{2}{|c|}{ Model } & \multicolumn{2}{|c|}{ Unstandardized Coefficients } & $\begin{array}{c}\begin{array}{c}\text { Standardized } \\
\text { Coefficients }\end{array} \\
\text { Beta } \\
\end{array}$ & $\mathrm{t}$ & Sig. \\
\hline \multirow[t]{5}{*}{1} & (Constant) & 2.655 & .345 & & 7.687 & .000 \\
\hline & Symbolic Frame & .414 & .246 & .588 & 1.98 & .048 \\
\hline & Human resource frame & .059 & .202 & .105 & .290 & .773 \\
\hline & Political frame & -.062 & .319 & -.093 & -.193 & .848 \\
\hline & Structural frame & -.032 & .281 & -.050 & -.114 & .909 \\
\hline
\end{tabular}

Dependent Variable: Unity of purpose

A significant regression equation was found $\left(F(4,50)=4.97, p<.05, R^{2}=.28\right.$. Symbolic action and behavior were predicted to have a positive effect on unity of purpose $(\mathrm{B}=.59, \mathrm{t}(53)=1.98, \mathrm{P}<.05)$. The result indicated that about59\% of the variation in unity of purpose was explained by symbolic orientation of the principal. An increase in the symbolic frame of school principals' leadership could increase the unity of purpose of teachers.

\section{SUMMARY, CONCLUSIONS AND IMPLICATIONS}

\subsection{Summary}

Based on the analysis and the findings, the following summaries of major findings are drawn:

1) The school principals use structural and political frame of leadership most often and the human resource and symbolic frames of leadership sometimes. The professional development, collegial support and unity of purpose cultures are the dominant school cultures identified, whereas the existence of the learning partnerships, teacher collaboration and collaborative leadership cultures were found to be average.

2) There were strong to moderate positive relationships among all leadership frames and all dimensions of school culture. Specifically, strong correlations were found between human resource frame and the two school culture factors of collegial support and teachers' collaboration; and between symbolic frames of leadership and school culture factors of collaborative leadership and unity of purpose. Others have all moderate positive relationship.

3) The human resource frame at $(\mathrm{B}=.59, \mathrm{t}(55)=3.76, \mathrm{P}=.006)$ and $(\mathrm{B}=.68, \mathrm{t}(55)=2.20, \mathrm{P}=.002)$ was found to have effects on teacher collaboration and learning partnership respectively. Each onepoint increase in human resource frame above their sample means predict .59 and. 68 point increases in teacher collaboration and learning partnership culture.

The symbolic frame at $(\mathrm{B}=.39, \mathrm{t}(55)=2.32, \mathrm{P}=.03$ and $(\mathrm{B}=.59, \mathrm{t}(55)=1.98, \mathrm{P}=.048)$ was found to have significant effect on collaborative leadership and unity of purpose in that order. Again, each one- point increase in symbolic frame above their sample means predicts .39 and .59 point increase in collaborative leadership and unity of purpose culture.

The structural frame at $(\mathrm{B}=.53, \mathrm{t}(55)=2.74, \mathrm{P}=.008)$ is found to have effects on professional development. Each one- point increase in structural frame above their sample means predict .53 point increase in professional development culture.

4) The school culture factor, collegial support was the only factor that was not significantly correlated with the leadership frames. 


\subsection{Conclusions}

The structural frame and political frames of leadership were often used by the case primary school principals of Ambo town. There were significant positive relationship between all the four principals' leadership frames and each of the school culture dimensions ranging from moderate to strong in strength. The human resource frame was a significant predictor of teacher collaboration and learning partnership cultures whereas symbolic frame was found a significant predicator of unity of purpose and collaborative leadership school cultures. Besides, the structural frame was found to affect significantly the professional development culture of the school.

The principals of the case schools focus on task accomplishment and on the use of legitimate power without considering the human and symbolic aspect of the organization. They emphasized rationality, analysis, logic, facts, and overall architecture of an organization in their leadership process. They also develop power bases and apply their negotiating skill to influence teachers. The leaders seem to follow the dominant thinking that teachers are there only to serve the school and to accomplish school objectives and that teachers are working because they are paid for the service. These approaches affected the culture of collaboration in the schools. Overall, it is concluded that Ambo town sampled primary school principals had a narrow view of school leadership orientation and consequently could not develop the functional culture in the school.

\subsection{Implications}

As per the findings of this study and the conclusion reached, several implications might be remarked for the participant principals and others in the field of educational leadership who might find relevant.

Modern leaders need to use more than one leadership orientation in order to better understand and improve schools. The ability to develop a broader, multi-framed perspective could put principals in a much better effectiveness position in developing collaborative school culture. Hence, the following suggestions are forwarded:

i) Universities and training institutions could utilize the results of this study to improve the relevance of the leadership curriculum and its mode of training to better prepare school principals for the leadership roles.

ii) Educational officials of various levels, specifically WEO experts, should regularly collect data on school culture and the leadership orientations of principals to identify the status of the school and then take appropriate measure in the development of school principals, such as short term training and other on job trainings.

iii) Principals need to see issues of leadership and management through different lenses before making decisions of partial and biased kind, and to use sized up mental structure in dealing with complex issues of school leadership and management.

iv) Principals should engage in re-culturing process to meet the needs of the time after making an intense awareness of the existing culture or diagnosing.

v) Supervisors need to supervise, mentor, and support principals to view school issues from multiple perspectives in the process of decision making.

\section{REFERENCES}

[1] Arthur-Kelly, M., Lyon, G., Butterfield, N., \& Gordon, C. (2006).Classroom management (2nd ed.). Melbourne, Australia: Nelson Australia.

[2] Baker, C.\& Campbell, M. (2013).Context matters: An Ethiopian case study, Adapting leadership development methods to serve different cultures (A White Paper). Center for Creative Leadership.

[3] Barker, J. A. (1990).The power of vision: Discussion guide. Burnsville, MN: Charterhouse Learning Corporation.

[4] Bensimon, E. M. (1989). The meaning of good presidential leadership: A frame analysis. Review of Higher Education, 12, 107-123. 
Improving School Leadership: Principals Orientation and Culture in Primary Schools of Ambo Town, Oromia Regional State, Ethiopia

[5] Bensimon, E. M. (1990). Viewing the presidency: Perceptual congruence between presidents and leaders on their campuses. Leadership Quarterly, 1, 71-90.

[6] Bass, B. M. (1985). Leadership and performance beyond expectation. New York: Free Press.

[7] Bass, B.M. (1991). Stogdill and Bass handbook for leadership: New York: The Free Press.

[8] Bolman, L. G., \& Deal, T. E. (1984).Modern approaches to understanding and managing organizations. San Francisco: Jossey-Bass.

[9] Bolman, L. G., \& Deal, T. E. (1990).Leadership orientations (Self). Brookline, MA: Leadership Frameworks.

[10] Bolman, L. G., \& Deal, T. E., (1991a).Images of leadership (NCEL Occasional Paper No. 7). Nashville, TN: National Center for Educational Leadership. (ERIC Document Reproduction Service No. ED 332345).

[11] Bolman, L. G., \& Deal, T. E., (1991b). Leadership and management effectiveness: A multiframe, multi-sector analysis. Human Resource Management, 30, 509-534.

[12] Bolman, L. G., \& Deal, T. E. (1992a).Everyday epistemology in school leadership: Patterns and prospects. Paper presented at the Annual Meeting of the American Educational Research Association in San Francisco, CA.

[13] Bolman\& Deal, T.E. (1991). Reframing organizations: Artistry, choice, and leadership. San Francisco: Josey-Bass Publishers.

[14] Bolman (1994).looking for leadership: Another search party's report. Educational Administration Quarterly, 30(1), pp.77+. Retrieved March 22, 2002 from EBSCO database on the World Wide Web: http://www.ebsco.com.

[15] Bolman, L. G., \& Deal, T. E. (1992b). Leading and managing: Effects of context, culture, and gender. Educational Administration Quarterly, 28, 314-329.

[16] Bolman, L. G., \& Deal, T. E. (1993). Everyday epistemology in school leadership: Patterns and

[17] prospects. In P. Hallinger, K. Leithwood, \& J. Murphy (Eds.), Cognitive perspectives on educational leadership (pp. 21-33). New York: Teachers College Press.

[18] Bolman, L. G., \& Deal, T. E. (2002).Reframing the path to school leadership: A guide for teachers and principals. Thousand Oaks, CA: Corwin Press.

[19] Bolman, L. G., \& Deal, T. E. (2003).Reframing organizations: Artistry, choice, and leadership. (3rd ed). San Francisco: Jossey-Bass.

[20] Bolman, L. G. (2008). Research with leadership orientations instrument. Retrieved July 2, 2008 from http://www.leebolman.com/orientations.htm.

[21] Brown, R. (2004). School culture and organization: Lessons from research and experience: A background paper for the Denver Commission on secondary school reform. Retrieved September 8, 2016, from http://www.dpsk12.org/ pdf/culture_organization.pdf

[22] Brown , P. , and Hesketh , A.( 2004). The Mismanagement of talent: Employability and jobs in the knowledge economy. New York : Oxford University Press.

[23] Bryman, A. (1993). Charismatic leadership in business organizations: Some neglected issues. Leadership Quarterly, 4, 289-304.

[24] Bush, T. (2003). Theories of educational leadership and management. London :SAGE.

[25] Busher, H. (2003).Principals and head teachers as chief executives.In L. Kydd, L. Anderson, \& W. Newton, (Eds.), Leading people and teams in education. London: Paul Chapman

[26] Butucha, KorsoGude( 2013).School type and school setting differences in teachers perceptions of school culture. International Journal of Education and Research Vol. 1 No. 12. 
[27] Cemaloglu, N. (2011). Primary principals' leadership styles, school organizational health, and workplace bullying.Journal of Educational Administration, 49(5), 495-512.

[28] Cheng, Yin Cheong (1994).Profiles of organizational culture and effective schools. school effectiveness and school improvement 4, 2 85-110.

[29] Cheng, Y. (1991). Leadership style of principals and organizational process in secondary schools. Journal of Educational Administration, 29, 25-37.

[30] Cheng, Y. C. (1993).Profiles of organizational culture and effective schools. School Effectiveness and School Improvement, 4 (2), pp. 85-110.

[31] Creswell, J. (2009) Research design: Qualitative, quantitative and mixed methods approaches. 3rd ed. US, UK \& India: Sage Publications.

[32] Cunningham, W.C. \& Gresso, D.W. (1993).Cultural Leadership: The culture of excellence in education. Boston: Allyn \& Bacon

[33] Davis, S. M. (1984). Managing corporate culture. Cambridge, MA: Ballinger.

[34] Day, C. et al. (2000). Leading schools in times of change. Buckingham, England.

[35] Open University Press.

[36] Day, C. (2000). Beyond transformational leadership. Educational Leadership, 57(7), pp. 56-59.

[37] Deal, T. E., \& Peterson, K. D. (1998). How leaders influence the culture of schools. Educational Leadership, 56(1), pp. 28-30.

[38] DuPont, J.P. (2009). Teacher perceptions of the influence of principal instructional leadership on school culture: A case study of the American embassy school in New Delhi, India. Unpublished doctoral dissertation. Minnesota, MN: University of Minnesota.

[39] Durocher, E. A. (1996). Leadership orientations of school administrators: A survey of nationally recognized school leaders. Dissertations Abstracts International, 57(02), 525A. (UMI No. 9620148)

[40] Elmore, R. F. (2002). The limits of change.Harvard Education Letter, 18(1), pp.8-15.

[41] Evans, L. (2003). Leadership role: Morale, job satisfaction and motivation. In L. Kydd, L.

[42] Anderson, \& W. Newton (Eds.), Leading people and teams in education (136-150).

[43] London: Paul Chapman.

[44] Fielding, M. (1999). Radical collegiality: Affirming teaching as an inclusive professional activity. The Australian Educational Researcher, 26(2), 1-34.

[45] Firestone, W. A. \& Wilson, B. L. (1985). Using bureaucratic and cultural linkages to improve instruction: The principal's contribution. Education Administration Quarterly, 21(2), pp. 7-30.

[46] Firestone, W. A., \& Wilson, B. L. (1995). Using bureaucratic and cultural linkages to improve instruction: The principal's contribution. Educational Administration Quarterly, 21(2), 7-30.

[47] Fullan,M.( 1992). Successful school in the implementation of perspective and beyond. Buckingham: Open University press.

[48] Fullan, M. ( 1992). Visions that blind.Educational Leadership 49 ( 5), 19-22.

[49] Fullan, M. (1993).Change forces. New York: Palmer.

[50] Fullan, M. (2001).Leading in a culture of change. San Francisco: Jossey-Bass.

[51] Fullan, M. (2002) The change leader. Educational leadership, May, pp. 16-21.

[52] Fullan, M., \& Hargreaves, A. (1996). What's worth fighting for in your school? New York: Teachers College Press. 
[53] Gentzler, Y. (2005). A new teacher's guide to best practices. Thousand Oaks, CA: Corwin Press

[54] Goldman, P. and Smith, N. (1991) Filling the frames: Using Bolman and Deal to analyze an educational innovation. ERIC ED355639

[55] Gruenert, S. (2000).Shaping a new school culture.Contemporary Education, 71(2), 14-17.

[56] Gruenert, S. (2005). Correlations of collaborative school cultures with student achievement. NASSP Bulletin, 89(645), 43-55.

[57] Gruenert, S., \& Valentine, J. (1998).School climate survey. Columbia, MO: Middle Level Leadership Center, University of Missouri.

[58] Gumuseli, A., \&Eryilmaz, A. (2011).The measurement of collaborative school culture on Turkish schools. New Horizons in Education, 59 (2), 13-26.

[59] Hallinger, P. (2011). Leadership for learning: Lessons from 40 years of empirical research. Journal of Educational Administration, 49(2), 125-142.

[60] Hallinger, P., \& Heck, R. H. (1998).Exploring the principal's contribution to school effectiveness: 1980-1995.School Effectiveness and School Improvement, 9, 157-191.

[61] Hofstede, G. H., \&Hofstede, G. J. (2005).Cultures and organizations: Software of the mind (Rev. and expanded 2 nd ed.). New York: McGraw-Hill.

[62] Hopkins, D., Ainscow, M., \& West, M. (1994).School improvement in an era of change. London: Cassell.

[63] Hoy, A. W., \& Hoy, W. K. (2006). Instructional leadership: A research based guide to learning in schools (2nd ed.). Boston: Allyn \& Bacon.

[64] Hoy, W. K., Tarter, C. J. \& Wool folk Hoy, A. (2006) Academic optimism of schools: a force for student achievement. American Educational Research Journal, 43 (3), 425-446.

[65] Jarzabkowski, Lucy, M. (2002).The social dimensions of teacher collegiality. Journal of Educational Enquiry, 3(2),45-65

[66] Jarzabkowski, L. M. (2003). Teacher collegiality in a remote Australian school. Journal of Research in Rural Education, 18 (3), 139144.

[67] Kythreotis, A., Pashiardis, P., \&Kyriakides, L. (2010).The influence of school leadership styles and culture onstudents' achievement in Cyprus primary schools. Journal of Educational Administration, 48(2), 218-240.

[68] Le Clear, E. A. (2005). Relationships among leadership styles, school culture, and student achievement (Doctoral Dissertation, University of Florida).

[69] Lee, S.H. (2008). A Study on the effects of Leadership style on the organizational effectiveness: verification of Bolman\& Deal's Frame Model, Doctoral Dissertation, Seokyeong University

[70] Lee-piggottrinnelle( NY ). New principals' leadership and school culture: A study of three primary schools facing challenging circumstances in Trinidad and Tobago.

[71] Leithwood, K., \& Sun, J. (2012). The nature and effects of transformational school leadership: A meta-analyticreview of unpublished research. Educational Administration Quarterly, 48(3), 387423.

[72] Leithwood, K., Riedlinger, B., Bauer, S., \&Jantzi, D. (2003). Leadership program effects on student learning: The case of the Greater New Orleans School Leadership Center.

[73] Journal of School Leadership and Management, 13(6), 707-738.

[74] Leithwood, K., \&Jantzi, D. (1990, June).Transformational leadership: How principals can help reform school cultures. Paper presented at the annual meeting of the 
[75] Canadian Association for Curriculum Studies, Victoria, British Columbia, Canada (ERIC Document Reproduction Service ).

[76] Levine, D.U., \&Lezotte, L.W (1990).Usually effective schools: A review and analysis of research and practice. Madison, WI: National centre for effective schools research and development.

[77] Little, J.W. (1990). The persistence of privacy: Autonomy and initiative in teachers' professional relations, Teachers College Record, 91 (4), pp.509-36.

[78] Martin, J. (2002). Organizational culture: Mapping the terrain. Thousand Oaks, CA: Sage.

[79] Martin, Shawn Terese (2009). Relationship between the leadership styles of principals and school culture. Electronic Theses \&Dissertations. Paper 269.

[80] Maurik,J.U.(1999). The effective strategist: Key skills for managers. Alder shot: Gower Publishing Ltd.

[81] Maslowski, R. (2006). A review of inventories for diagnosing school culture. Journal of Educational Administration, 44 (1), pp. 6-35.

[82] Mozaffari, F., Amin (2008).A Study of relationship between organizational culture and leadership. University of Tabriz. International Conference on Applied Economics - ICOAE 2008679.

[83] Newmann, F. M., \& Associates.(1996). School restructuring and authentic student achievement.

[84] San Francisco: Jossey-Bass.

[85] Peterson, K. D. (2002). Positive or negative?Journal of Staff Development, 23(3), 10-15.

[86] Raywid, M. A. (2001). School culture. Viewp oints: Small by design: Resizing America's high schools. Retrieved November 5, 2008, from http://www.smallschools project.org/ PDFS/ culture. pdf

[87] Reitzug, U. C., \&Revves, J. E. (1992). Miss Lincoln doesn't teach here: A descriptive narrative and conceptual analysis of a principal's symbolic leadership behavior. Education Administration Quarterly. 28, 185-219.

[88] Renchler, Ron (1992). Student Motivation, School Culture, and Academic Achievement: What School Leaders Can Do.Trends and Issues Series. Eugene, Oregon: ERIC Clearinghouse on Educational Management., University of Oregon, Roberts, C. (2004). The dissertation journey. Thousand Oaks, CA: Corwin Press

[89] Rosenholtz, S.J. (1989). Teachers' workplace: The social organization of schools. New York: Longman

[90] Sarason,S.(1996). Revisiting the culture of the school and the problem of change.New York:Teacher college press.

[91] Sashkin, Marshall, and Sashkin, Molly G. (1990). Leadership and culture building in schools: Quantitative and qualitative understandings. Paper presented at the annual meeting of the American Educational Research Association, Boston, April 16-20.

[92] Schein, E.H. (1990). Organizational culture. American Psychologist, 45 (2), pp. 109-119.

[93] Schein, E. (1992). Organizational culture and leadership: A dynamic view. San Francisco: Jossey-Bass.

[94] Schein, E. (2004). Organizational culture and leadership( $3^{\text {rd }}$ ed.): San Francisco: Jossey-Bass.

[95] Sergiovanni, T. J. (2000). The life world of leadership. San Francisco: Jossey-Bass.

[96] Shah, Madiha( 2012). The importance and benefits of teacher collegiality in schools a Literature review. Procedia - Social and Behavioral Sciences 46, 1242 - 1246 
[97] Sheilds, C. (2005). School leadership in the 21st Century: Broadening the base..In Hoy, W., \&Miskel, C. Educational leadership and Reform. Connecticut : Information Age Publishing.

[98] Snowden, P. E. \& Gorton, R. A. (1998).School leadership and administration: Important concepts, case studies, and simulations (5th ed.). New York: McGraw-Hill.

[99] Stoll, L. (1998). School culture. School Improvement Network's Bulletin, 9, 9-14.

[100] Stolp, S. W. (1994). Transforming school culture: Stories, symbols, values \& the leader's role. Eugene, OR: ERIC Clearinghouse.

[101] Stolp, S.W. \&. Smith, S.C. (1995) Transforming school culture: stories, symbols, values, and the leader's role. US: Eric Clearinghouse on Educational Management, University of Oregon.

[102] Stolp, Stephen, and Stuart C. Smith ( 1995). School culture and climate: the role of the leader. OSSC Bulletin. Eugene: Oregon School Study Council.

[103] Thompson, M. D. (2000). Gender, leadership orientation, and effectiveness: Testing the theoretical models of Bolman\& Deal and Quinn. Sex Roles, 42, 969-992.

[104] Trice, H. M. (1993).Occupational subcultures in the workplace. New York: Cornell University Press.

[105] Valentine Jerry ( 2006):A Collaborative Culture for School Improvement: Significance, Definition, and Measurement, Research Summary. Middle Level Leadership Center

[106] Yukl, G. A. (1989). Leadership in organizations (2nd ed.). Englewood Cliffs, NJ: Prentice Hall 